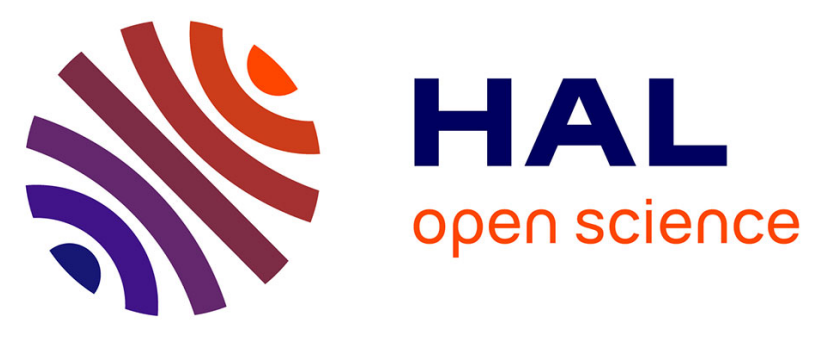

\title{
The FHA-containing protein GarA acts as a phosphorylation-dependent molecular switch in mycobacterial signaling.
}

Patrick England, Annemarie Wehenkel, Sonia Martins, Sylviane Hoos, Gwenaëlle André-Leroux, Andrea Villarino, Pedro M Alzari

\section{To cite this version:}

Patrick England, Annemarie Wehenkel, Sonia Martins, Sylviane Hoos, Gwenaëlle André-Leroux, et al.. The FHA-containing protein GarA acts as a phosphorylation-dependent molecular switch in mycobacterial signaling.. FEBS Letters, 2009, 583 (2), pp.301-7. 10.1016/j.febslet.2008.12.036 . hal02660100

\section{HAL Id: hal-02660100 \\ https: / hal.inrae.fr/hal-02660100}

Submitted on 30 May 2020

HAL is a multi-disciplinary open access archive for the deposit and dissemination of scientific research documents, whether they are published or not. The documents may come from teaching and research institutions in France or abroad, or from public or private research centers.
L'archive ouverte pluridisciplinaire HAL, est destinée au dépôt et à la diffusion de documents scientifiques de niveau recherche, publiés ou non, émanant des établissements d'enseignement et de recherche français ou étrangers, des laboratoires publics ou privés.

\section{()(1)(2)}

Distributed under a Creative Commons Attribution - ShareAlikel 4.0 International 


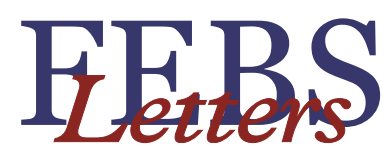

journal homepage: www.FEBSLetters.org

\title{
The FHA-containing protein GarA acts as a phosphorylation-dependent molecular switch in mycobacterial signaling
}

\author{
Patrick England ${ }^{\mathrm{a}, \mathrm{b}}$, Annemarie Wehenkel ${ }^{\mathrm{a}}$, Sonia Martins ${ }^{\mathrm{b}}$, Sylviane Hoos ${ }^{\mathrm{b}}$, Gwénaëlle André-Leroux ${ }^{\mathrm{a}}$, \\ Andrea Villarino ${ }^{\mathrm{a}, 1}$, Pedro M. Alzari ${ }^{\mathrm{a}, *}$ \\ a Institut Pasteur, Unité de Biochimie Structurale E CNRS URA 2185, 25 rue du Docteur Roux, F-75724 Paris, France \\ ${ }^{\mathrm{b}}$ Institut Pasteur, Plateforme de Biophysique des Macromolécules et de leurs Interactions \& CNRS URA 2185, 25 rue du Docteur Roux, F-75724 Paris, France
}

\section{A R T I C L E I N F O}

\section{Article history:}

Received 16 October 2008

Revised 5 December 2008

Accepted 16 December 2008

Available online 27 December 2008

Edited by Gianni Cesareni

\section{Keywords:}

FHA domain

Signal transduction

Calorimetry

Physical chemistry

Mycobacterium tuberculosis

\begin{abstract}
A B S T R A C T
Fork-head associated (FHA) domains are widely found in bacteria, but their cellular functions remain unclear. Here, we focus on Mycobacterium tuberculosis GarA, an FHA-containing protein conserved in actinomycetes that is phosphorylated by different Ser/Thr protein kinases. Using various physicochemical approaches, we show that phosphorylation significantly stabilizes GarA, and that its FHA domain interacts strongly with the phosphorylated N-terminal extension. Altogether, our results indicate that phosphorylation triggers an intra-molecular protein closure, blocking the phosphothreonine-binding site and switching off the regulatory properties of GarA. The model can explain the reported functions of this mycobacterial protein as regulator of glycogen degradation and glutamate metabolism.

Structured summary:

MINT-6804218: GarA (uniprotkb:P64897) and GarA (uniprotkb:P64897) bind (MI:0407) by isothermal titration calorimetry (MI:0065)
\end{abstract}

(c) 2008 Federation of European Biochemical Societies. Published by Elsevier B.V. All rights reserved.

\section{Introduction}

Modular protein adaptors act in concert with Ser/Thr/Tyr protein kinases and phosphatases to setup dynamic signaling cascades and protein-protein interaction networks [1]. Long believed to be a distinctive feature of higher eukaryotes, these sophisticated regulation and signaling mechanisms are also emerging as fundamental features in some bacterial species. This is notably the case for one of the deadliest human pathogens, Mycobacterium tuberculosis. The mycobacterial genome [2] revealed the presence of many "eukaryotic-like" signaling elements, including several genes coding for Ser/Thr protein kinases and phosphatases [3] as well as various proteins containing fork-head associated (FHA) domains $[4,5]$.

FHA domains are protein modules composed of 100-120 residues folded into a characteristic 11-strand beta-sandwich fold.

Abbreviations: AUC, analytical ultracentrifugation; CD, circular dichroism; DLS, dynamic light scattering; DSC, differential scanning calorimetry; FHA, Fork-head associated; ITC, isothermal titration calorimetry; MALS, multi-angle light scattering; PAGE, polyacrylamide gel electrophoresis; SELDI-TOF, surface-enhanced laser desorption ionization time-of-flight.

* Corresponding author. Fax: +33145688604.

E-mail address: alzari@pasteur.fr (P.M. Alzari).

${ }^{1}$ Present address: Institut Pasteur de Montevideo, Mataojo 2020, Montevideo Uruguay.
These domains act as phosphorylation-dependent protein-protein interaction modules that preferentially bind to phospho-threonine residues in their targets and seem to be particularly prevalent in proteins involved in cell cycle control [6], although their molecular functions are still poorly understood. Here, we focus on $M$. tuberculosis GarA, a protein that is highly conserved in mycobacteria and corynebacteria, but totally absent in eukaryotes. $M$. tuberculosis GarA is a 162-residues protein harboring a C-terminal FHA domain preceded by an $\mathrm{N}$-terminal peptide extension of about 50 residues (Fig. 1). GarA was found to be the optimal substrate of the Ser/Thr protein kinase PknB in mycobacterial protein extracts [7], and both GarA and its Corynebacterium glutamicum ortholog, OdhI (82\% sequence identity), were shown to be phosphorylated by protein kinase PknG $[8,9]$. In both cases, the protein is specifically phosphorylated on a single Thr residue in a highly conserved ETTS motif at the middle of the $\mathrm{N}$-terminal peptide extension (Fig. 1).

We report here the effect of GarA phosphorylation on the physico-chemical and structural properties of the protein. Our results point to a mechanism by which phosphorylation at the ETTS motif induces an intra-molecular shutdown of the regulatory properties of the protein, through a tight self-recognition of the phosphorylated N-terminal extension by the C-terminal FHA domain. The ensuing model is consistent with, and can account for, the apparent functional promiscuity of GarA in actinomycetes [8-10]. 


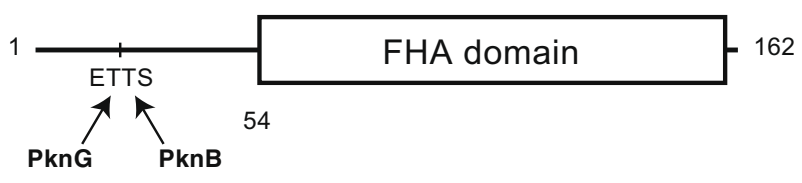

Fig. 1. Modular organization of M. tuberculosis GarA, composed of a C-terminal FHA domain and an N-terminal peptide extension including the phosphorylatable ETTS motif (corresponding to positions 20-23), which is highly conserved in GarA homologs from actinomycetes. Protein kinase PknB phosphorylates Thr22 and PknG phosphorylates Thr21.

\section{Materials and methods}

\subsection{Production of proteins and peptides}

The gene encoding $M$. tuberculosis GarA was cloned into the pDEST17 expression vector (Invitrogen). Transformed Escherichia coli BL21(DE3)-pLysS cells were grown in HDM2 medium in $70 \mathrm{ml}$ micro-fermentors, first at $30^{\circ} \mathrm{C}$ until a $\mathrm{OD}_{600 \mathrm{~nm}}$ of 20 , then for $16 \mathrm{~h}$ at $14{ }^{\circ} \mathrm{C}$ after addition of $1 \mathrm{mM}$ IPTG (final $\mathrm{OD}_{600} \mathrm{~nm}$ between 60 and 70). The C-terminal FHA domain of GarA (GarA ${ }_{\Delta 43}$, comprising residues 44-162) was cloned into the pET-28A(+) vector (Invitrogen) using T4 DNA ligase (Biolabs). Transformed E. coli BL21(DE3)pLysS cells were grown in LB medium supplemented with kanamycin and chloramphenicol, first at $30^{\circ} \mathrm{C}$ until a $\mathrm{OD}_{600 \mathrm{~nm}}=0.8$ was reached, then for $16 \mathrm{~h}$ at $14{ }^{\circ} \mathrm{C}$ after addition of $1 \mathrm{mM}$ IPTG.

In both cases, the cells were harvested by centrifugation, resuspended in buffer A (25 mM HEPES, $500 \mathrm{mM} \mathrm{NaCl}, 20 \%$ glycerol, $1 \mathrm{mM}$ DTT, $20 \mathrm{mM}$ imidazole, pH 8.0) supplemented with Complete Protease Inhibitor Cocktail (Roche), and lysed at $4{ }^{\circ} \mathrm{C}$ with an EmulsiFlex C5 high-pressure homogenizer (Avestin). The supernatant was cleared by centrifugation and passage through a Minisart $0.2 \mu \mathrm{M}$ filter (Sartorius). The proteins were first purified by metal-affinity chromatography on a nickelloaded HisTrap HP column (GE Healthcare). Protein-containing fractions were dialysed against buffer B (25 mM HEPES, $100 \mathrm{mM} \mathrm{NaCl}, 5 \%$ glycerol, $1 \mathrm{mM}$ DTT, pH 8.0), and the $\mathrm{His}_{6}$ tag was removed by incubation for $24 \mathrm{~h}$ at $18^{\circ} \mathrm{C}$ in the presence of $\mathrm{His}_{6}$-tagged TEV endoprotease at a 1:70 ratio followed by separation on Ni-NTA agarose column (Qiagen). The untagged recombinant proteins were then further purified by size-exclusion chromatography on a Superdex 75 column (GE Healthcare) equilibrated in buffer B. All concentrations were determined by UV/ visible spectrophotometry and amino acid analysis after $6 \mathrm{~N}$ $\mathrm{HCl}$ hydrolysis, using a norleucine standard.

Two HPLC-purified peptides of sequence SDEVTVETTSVFRADFL, containing either a Thr or a phosphoThr residue at the central position (in bold), were obtained from Thermo Electron Corporation (Ulm, Germany). The lyophilized peptides were dissolved in $25 \mathrm{mM}$ HEPES, $100 \mathrm{mM} \mathrm{NaCl}, \mathrm{pH}$ 8.0, and their concentration was adjusted to $250 \mu \mathrm{M}$.

\subsection{Phosphorylation assays}

To obtain monophosphorylated GarA ( $\operatorname{Gar} \mathrm{A}_{\mathrm{pT} 22}$ ), the protein $(250 \mu \mathrm{M})$ was incubated with $M$. tuberculosis Ser/Thr protein kinase PknB $(15 \mu \mathrm{M})$ for $5 \mathrm{~h}$ at $30^{\circ} \mathrm{C}$ in buffer B supplemented with $5 \mathrm{mM} \mathrm{MgCl}_{2}$ and $0.5 \mathrm{mM}$ ATP. The completeness of phosphorylation was assessed by controlling that the GarA band was totally shifted upwards in a $15 \%$ acrylamide SDS-polyacrylamide gel electrophoresis (PAGE) gel, and that a single peak corresponding to phosphorylated GarA was detected by mass spectrometry (surface-enhanced laser desorption ionization time-of-flight (SELDI-TOF), Ciphergen Bio-Rad).

\subsection{Limited proteolysis}

GarA $(180 \mu \mathrm{g} / \mathrm{ml})$ was incubated with papain $(0.45 \mu \mathrm{g} / \mathrm{ml})$, elastase $(1.4 \mu \mathrm{g} / \mathrm{ml})$, or endoproteinase Glu-C $(1.25 \mu \mathrm{g} / \mathrm{ml})$ for $90 \mathrm{~min}$ at $25^{\circ} \mathrm{C}$. The buffer used was $10 \mathrm{mM}$ phosphate, $\mathrm{pH} 7.0$ (papain, endo-GluC) or $50 \mathrm{mM}$ HEPES, pH 8.0 (elastase). Proteolysis was stopped with $1 \mathrm{mM}$ iodoacetamide (papain) or $1 \mathrm{mM}$ PMSF (elastase, endoGlu-C), and the reaction products analysed by SDS-PAGE.

$\mathrm{N}$-terminal peptide sequences were determined by Edman degradation on an Applied Biosystems 473A sequencer. The molecular mass of the fragments was determined by SELDI-TOF spectrometry, after adsorption on an $\mathrm{H} 4$ reverse phase ProteinChip Array (Ciphergen Bio-Rad).

\subsection{Analytical ultracentrifugation (AUC)}

Experiments were conducted at $25{ }^{\circ} \mathrm{C}$ in a ProteomeLab XL-I analytical ultracentrifuge (Beckman-Coulter) equipped with an interference optical detection system. For sedimentation velocity experiments, protein samples $(57,19$ and $6.3 \mu \mathrm{M}$, in $25 \mathrm{mM}$ HEPES, $100 \mathrm{mM} \mathrm{NaCl}, \mathrm{pH} 8.0$ ) were spun at $50000 \mathrm{rpm}$ for $4 \mathrm{~h}$, using an AnTi50 eight-hole rotor and $1.2 \mathrm{~cm}$ path-length double-sector aluminium center pieces. Interference fringe displacement profiles were monitored at 1-min intervals, and data were analyzed with the SEDFIT software (www.analyticalultracentrifugation.com), using a model for continuous sedimentation coefficient distribution $c(s)$ with deconvolution of diffusional effects. Distributions were calculated with maximum entropy regularization at a predetermined confidence level of one standard deviation.

For sedimentation equilibrium experiments, protein samples (75, 25 and $8.3 \mu \mathrm{M}$ in $25 \mathrm{mM}$ HEPES, $100 \mathrm{mM} \mathrm{NaCl}$ ) were sequentially spun at 18000,24000 and $30000 \mathrm{rpm}$. After reaching equilibrium at each speed (typically after $18 \mathrm{~h}$ ), 10 successive scans were recorded and the protein radial distributions were globally analyzed with the Origin7 (OriginLab) and SEDPHAT softwares.

\subsection{Multi-angle light scattering (MALS)}

Protein samples ( $25 \mu \mathrm{M}$ in $25 \mathrm{mM}$ HEPES, $100 \mathrm{mM} \mathrm{NaCl}, \mathrm{pH} 8.0$ ) were injected onto a Biosuite 125 HPLC size-exclusion column (Waters) connected with a DAWN-EOS multi-angle light scattering detector and an OptilabRex refractometer (Wyatt). The HPLC column and the detectors were equilibrated at $25^{\circ} \mathrm{C}$ in the sample buffer at a flow rate of $0.5 \mathrm{ml} / \mathrm{min}$. The detector responses were calibrated and normalized by measuring the signal for monomeric bovine serum albumin. A value of $0.185 \mathrm{ml} / \mathrm{g}$ was assumed for the refractive index increment $(d n / d c)$ of the protein.

\subsection{Dynamic light scattering (DLS)}

Photon correlation experiments were performed at $25^{\circ} \mathrm{C}$ with a DynaPro MS800 instrument (Wyatt). For each sample $(25 \mu \mathrm{M}$ in $25 \mathrm{mM}$ HEPES, $100 \mathrm{mM} \mathrm{NaCl}, \mathrm{pH} 8.0$ ), the total light scattered at an angle of $90^{\circ}$ was collected using a $10 \mathrm{~s}$ averaging acquisition time. Particle translational diffusion coefficients $\left(D_{\mathrm{T}}\right)$ were calculated from the autocorrelated light intensity data and converted to hydrodynamic radii $\left(R_{\mathrm{H}}\right)$ with the Stokes-Einstein equation. Distribution plots of intensity versus $R_{\mathrm{H}}$ were done with the SEDFIT software.

\subsection{Circular dichroism $(C D)$}

CD spectra were measured with an Aviv 215 spectropolarimeter (Aviv Biomedical). Far-UV CD spectra were acquired at $25^{\circ} \mathrm{C}$ using a cylindrical cell with a $0.02 \mathrm{~cm}$ path-length. The samples $(0.36 \mathrm{mg} / \mathrm{ml}$ in $25 \mathrm{mM}$ phosphate, $100 \mathrm{mM} \mathrm{NaF}, \mathrm{pH} 8.0)$, were 
scanned over two adjacent spectral ranges, one from 260 to $200 \mathrm{~nm}(0.5 \mathrm{~nm}$ step) with an averaging time of $1 \mathrm{~s}$ per step, the second from 200 to $178 \mathrm{~nm}$ ( $0.5 \mathrm{~nm}$ step) with an averaging time of $4 \mathrm{~s}$ per step. Both regions were scanned consecutively three times. The individual spectra from the two regions were merged and the resulting three data files were averaged. The spectra, corrected using buffer baselines measured under the same conditions, were normalised to the molar peptide bond concentration and path-length $(1 \mathrm{~cm})$ as mean molar differential extinction coefficient per residue $(\Delta \varepsilon)$. Secondary structure estimations were derived using the CONTIN/LL method included in the CDPro software.

Near-UV CD spectra were measured between 350 and $250 \mathrm{~nm}$, with a constant $0.5 \mathrm{~nm}$ step and $1 \mathrm{~s}$ per step averaging time, using a $1 \mathrm{~cm}$ path-length rectangular cell (proteins at $1.5 \mathrm{mg} / \mathrm{ml}$ in $25 \mathrm{mM}$ HEPES, $100 \mathrm{mM} \mathrm{NaCl}, \mathrm{pH}$ 8.0). Each protein spectrum was corrected by the corresponding averaged buffer background signal and normalised to the molar concentration of peptide chain.

Thermally induced unfolding of protein samples $(20 \mu \mathrm{M}$ in $25 \mathrm{mM}$ phosphate, $100 \mathrm{mM} \mathrm{NaF}, \mathrm{pH}$ 8.0) was monitored in a cuvette with an $0.2 \mathrm{~cm}$ path-length by following the change in $\mathrm{CD}$ signal at $215 \mathrm{~nm}$ over a temperature range of $25-90^{\circ} \mathrm{C}$, with a heating rate of $0.75{ }^{\circ} \mathrm{C} / \mathrm{min}$. The curves were fitted with a two-state model using previously described equations [11].

\subsection{Differential scanning calorimetry (DSC)}

Endotherms were measured using a VP-DSC calorimeter (MicroCal). Samples $(40 \mu \mathrm{M}$ in $25 \mathrm{mM}$ phosphate, $100 \mathrm{mM} \mathrm{NaF}, \mathrm{pH}$
8.0) were degassed under vacuum for $10 \mathrm{~min}$ with gentle stirring prior to loading into the calorimetric cell $(0.5 \mathrm{ml})$. After equilibration for $30 \mathrm{~min}$ at $25^{\circ} \mathrm{C}$, the samples were heated over a temperature range of $25-90^{\circ} \mathrm{C}$ at a constant rate of $0.7^{\circ} / \mathrm{min}$. After subtracting a buffer-reference thermogram, the resulting excess heat capacity curves were analyzed using a two-state model with the Origin7 software (OriginLab).

\subsection{Isothermal titration calorimetry (ITC)}

$\operatorname{GarA}_{\triangle 43}$ and the synthetic peptides were diluted in $25 \mathrm{mM}$ HEPES, $100 \mathrm{mM} \mathrm{NaCl}, \mathrm{pH} 8.0$ and thoroughly degassed. GarA $\mathrm{A}_{\Delta 43}$ $\left(15 \mu \mathrm{M}\right.$ in the $1.4 \mathrm{ml}$ cell) was then titrated at $25^{\circ} \mathrm{C}$ by $5 \mu \mathrm{l}$ injections of peptide ( $250 \mu \mathrm{M}$ in the syringe), using a VP-ITC calorimeter (MicroCal). Raw data were normalized and corrected for heats of dilution of the peptides. Binding stoichiometries, enthalpy values and equilibrium dissociation constants were determined by fitting the corrected data to a bimolecular interaction model using the Origin7 software (OriginLab).

\section{Results and discussion}

\subsection{Phosphorylation has little effect on the overall structure of GarA}

The radial distributions obtained by AUC sedimentation/diffusion equilibrium studies could be optimally fitted using a singleideal species model, yielding buoyant molecular masses of 16813 $( \pm 633) \mathrm{Da}$ for GarA (theoretical MW: 17176) and 17278
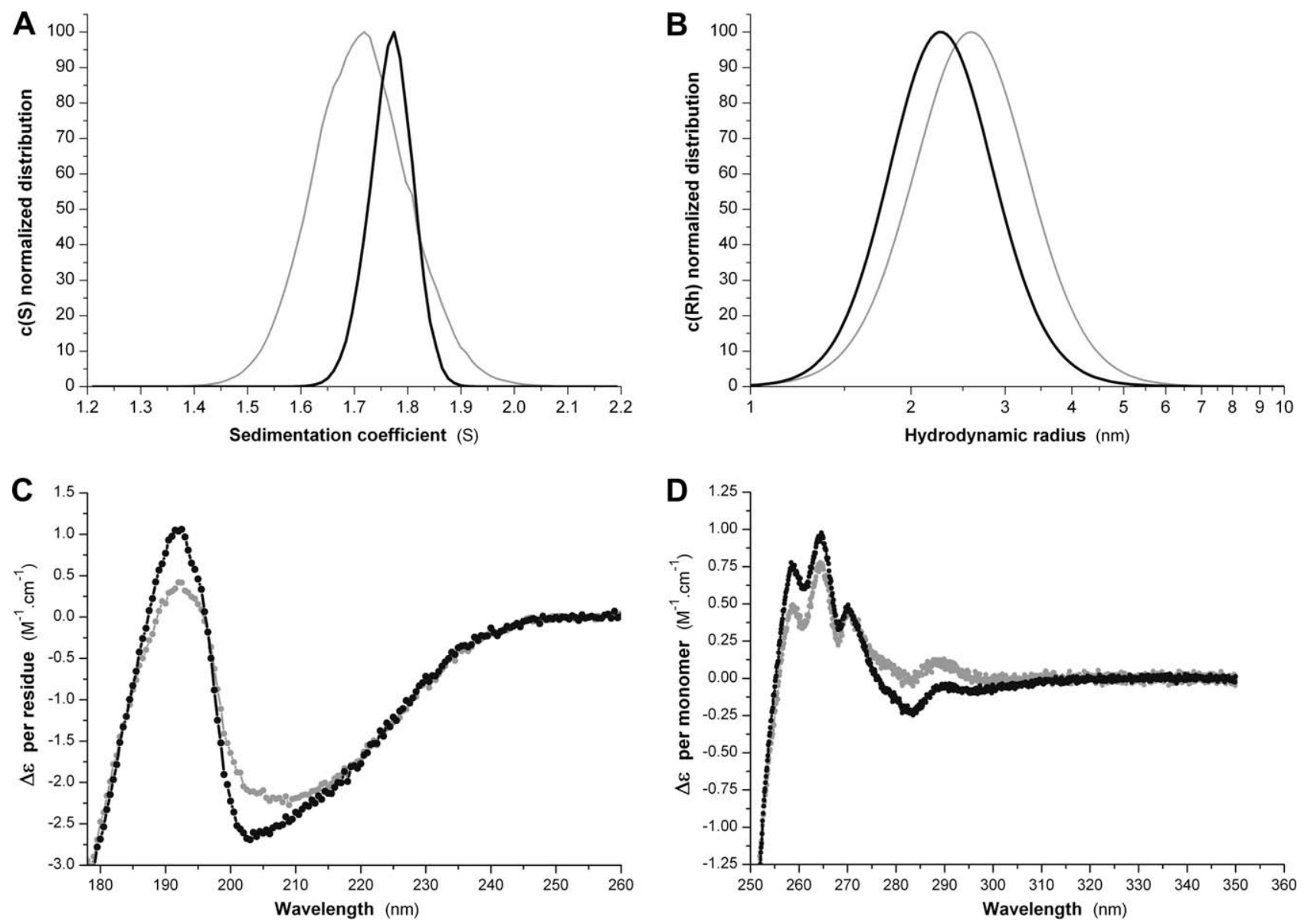

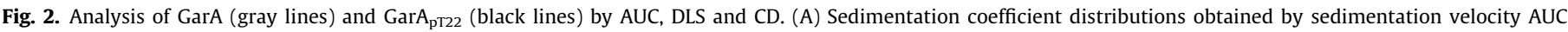

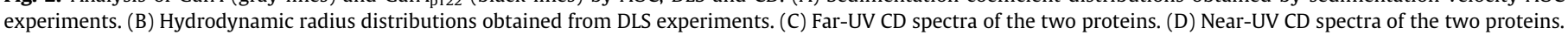


( \pm 855 ) Da for GarA $A_{\text {pT22 }}$ (theoretical MW: 17258) (data not shown). The MALS experiment further confirmed these results, as both forms of the protein were eluted from the HPLC column as single peaks with virtually the same time retention and static light scattering plateaux corresponding to a molecular mass between 16500 and $17500 \mathrm{Da}$. Thus, the above studies showed that GarA behaves as a monomer in solution, and that protein phosphorylation does not change the oligomerization state of the protein.

We then asked whether phosphorylation could promote a detectable change of protein shape or conformation. The sedimentation coefficient distributions obtained using analytical centrifugation showed that only one species is present for each protein (Fig. 2A). Likewise, hydrodynamic radial distributions from quasielastic light scattering experiments showed a single species in each case, centered around a value of $2.6 \mathrm{~nm}$ for GarA and $2.2 \mathrm{~nm}$ for $\operatorname{Gar}_{\text {pT22 }}$ (Fig. 2B). The narrower peaks for the phosphorylated form of the protein in sedimentation velocity experiments indicate a less polydisperse, more compact shape, suggesting that phosphorylation may result in a loss of intrinsic flexibility of the protein.

The far-UV (178-250 nm) CD spectra of the protein, with a deep minimum in the $200-210 \mathrm{~nm}$ region confirmed that GarA consisted principally of $\beta$-sheets (Fig. 2C). Deconvolution of the spectra showed that GarA contained approximately 7\% $\alpha$-helix, 30\% $\beta$ sheet, and $24 \% \beta$-turn, with $39 \%$ of the residues belonging to structurally undefined regions. Upon phosphorylation, a slight blueshift and deepening of the minimum, as well as a sharpening of the maximum around $190 \mathrm{~nm}$, was observed, which is consistent with a moderate increase in the content of secondary structure ( $9 \% \alpha-$ helix, $34 \% \beta$-sheet) at the expense of structurally undefined regions (34\%). Furthermore, the near-UV (250-350 nm) CD spectra showed marked maxima and minima, indicating that most aromatic residues of the protein are positioned in well-structured tertiary environments (Fig. 2D). This observation is in agreement with a 3D homology model of the protein, based on the structure of the FHA domain of M. tuberculosis EmbR [12] as template. The only Tyr residue in the GarA sequence and 6 (out of 8 ) Phe residues are found within the C-terminal FHA domain. Furthermore, phosphorylation of GarA induced only small changes of the spectra, suggesting that the local structural environments of the aromatic residues are not significantly modified by phosphorylation.

\subsection{GarA phosphorylation significantly increases the thermal stability of the protein}

Although the above studies indicate only moderate effects of PknB phosphorylation on the overall structure of GarA, the thermal stability of the protein was remarkably influenced by phosphorylation. The temperature-induced unfolding of GarA and GarA $\mathrm{A}_{\mathrm{pT} 22}$ was studied using CD and DSC. In all cases, the melting profiles correctly fit a simple two-state transition. Most interestingly, the

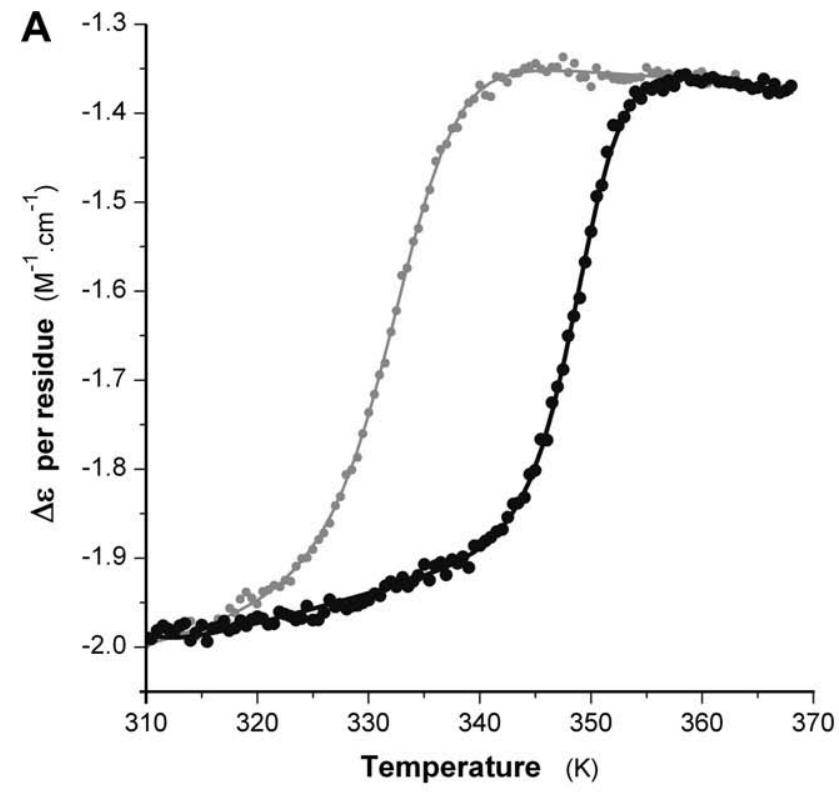

B

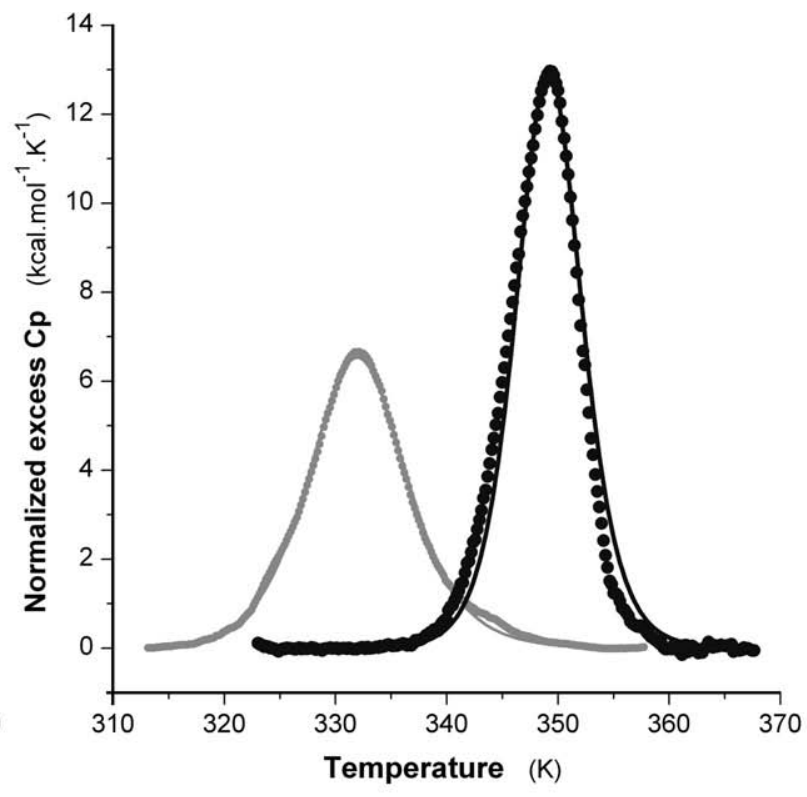

Time $(\mathrm{min})$

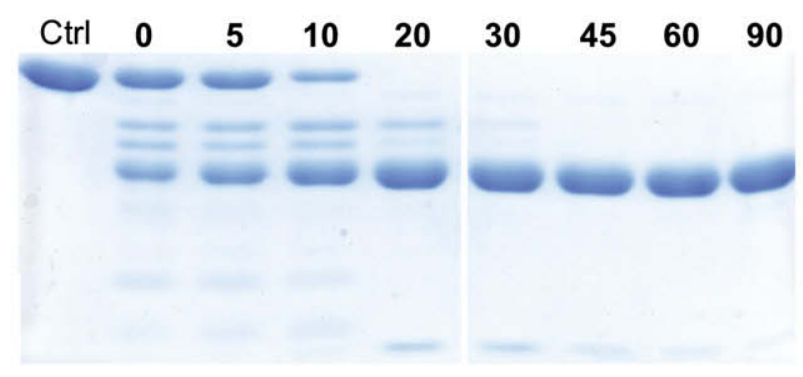

Unphosphorylated GarA

\section{Phosphorylated GarA}

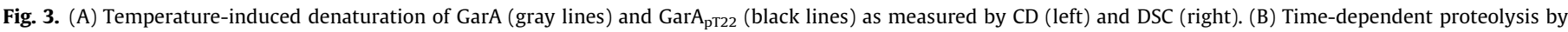
papain of GarA (left) and GarA $\mathrm{AT2}_{22}$ (right). 
two methods showed that Thr22 phosphorylation promoted a significant increase $(>15 \mathrm{~K})$ in the melting temperature of GarA (Fig. 3A). The calorimetric enthalpies $\Delta H$ of unfolding are $70.4 \pm 0.4 \mathrm{kcal} \mathrm{mol}^{-1}$ for GarA and $109.6 \pm 1.7 \mathrm{kcal} \mathrm{mol}^{-1}$ for Gar$\mathrm{A}_{\text {pт22. }}$. Assuming a $\triangle C p$ value of $2.44 \mathrm{kcal} \mathrm{mol}^{-1} \mathrm{~K}^{-1}$ [13], the estimated free energies of unfolding $(\Delta G)$ are, respectively $2.8 \mathrm{kcal} \mathrm{mol}^{-1}$ and $6.5 \mathrm{kcal} \mathrm{mol}^{-1}$. Furthermore, a comparable in- crease in melting temperature was observed when GarA was phosphorylated by PknG on Thr21 (data not shown), indicating that phosphorylation of either Thr residue within the ETTS motif produces a similar protein stabilization effect.

The small effects of phosphorylation on the structural core of the FHA domain (Fig. 2) suggest that thermal stabilization might be primarily associated with the structuring of the N-terminal

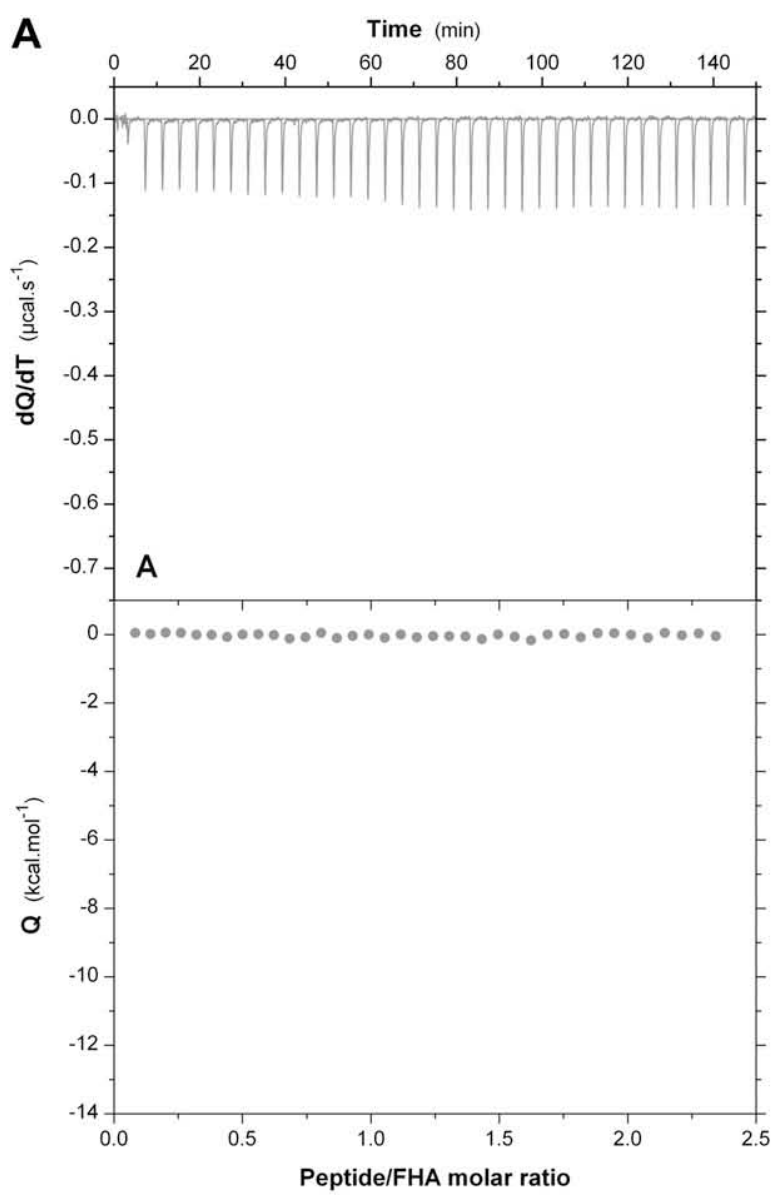

B

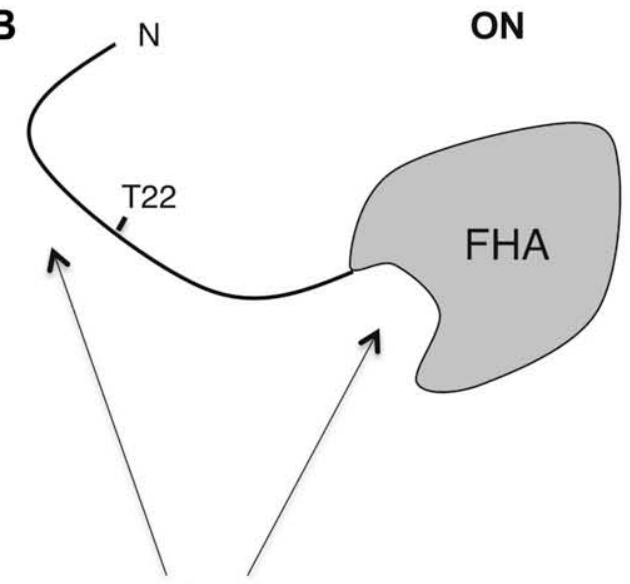

Accessible sites for protein-protein interactions

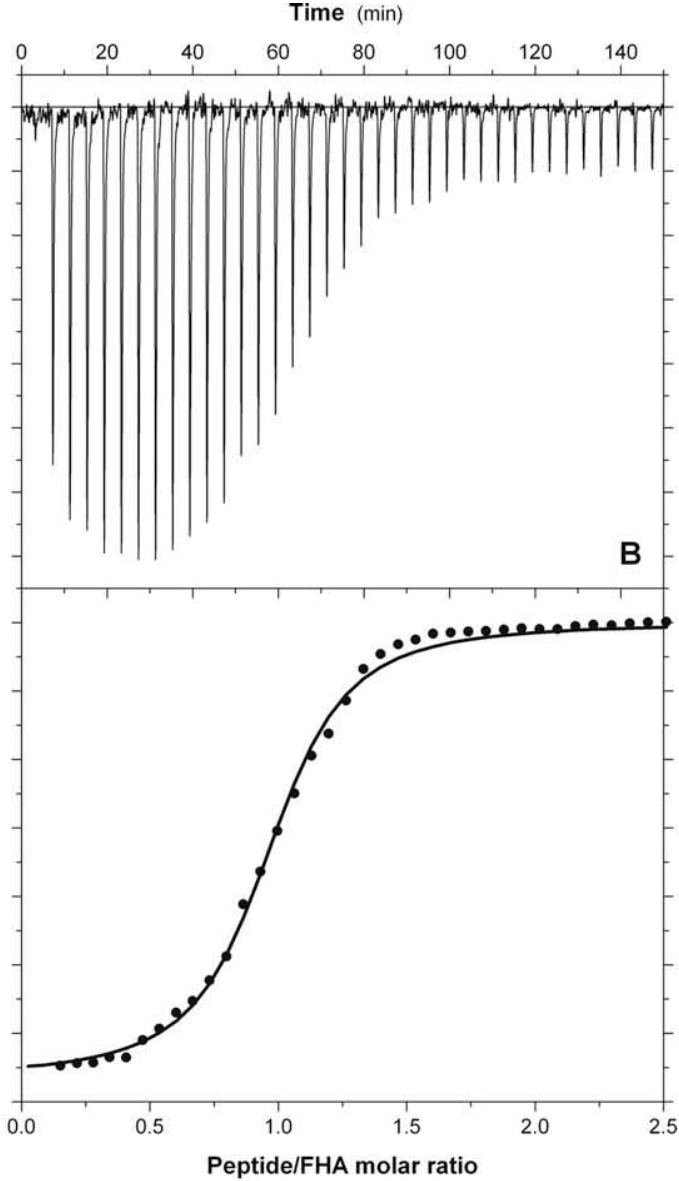

OFF

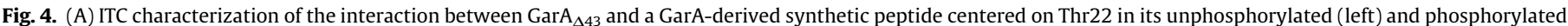

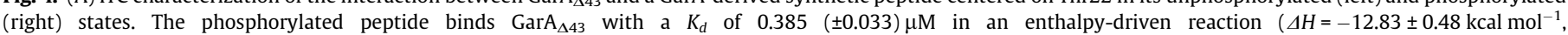

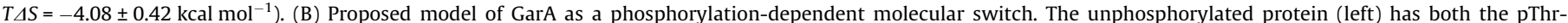

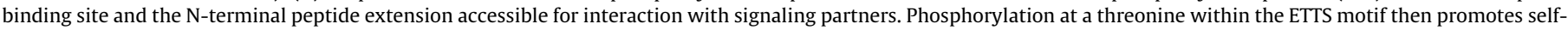
recognition (right), effectively blocking the FHA binding site and switching off the regulatory functions of the protein. 
peptide extension upon phosphorylation. Two experimental observations lend strong support to this hypothesis. First, digestion of unphosphorylated GarA by three different proteases under mild conditions quickly produced smaller fragments of the protein, in all cases with the cleavage sites within the N-terminal extension, indicating a high accessibility of this region to proteases (Fig. 3B). As determined by peptide sequencing, endoGluC cleaved GarA after residues Glu20 and Glu32, while both elastase and papain treatments generated a single major fragment of $12.5 \mathrm{kDa}$, which starts at Ala44 and corresponds roughly to the C-terminal FHA domain. In contrast, phosphorylation significantly protected GarA against proteolysis by papain and endoproteinase $\mathrm{Glu}-\mathrm{C}$, as virtually no cleavage could be seen under the same experimental conditions over a time period of $90 \mathrm{~min}$ (Fig. 3B).

Secondly, we constructed a recombinant protein lacking the $\mathrm{N}$ terminal region and including only the FHA fragment as defined by proteolysis, which corresponds to residues 44-162 of GarA $\left(\operatorname{Gar}_{\Delta 43}\right)$. The unfolding parameters of $\mathrm{GarA}_{\Delta 43}$ were measured by DSC and found to be very similar to those of full-length GarA $\left(T_{\mathrm{m}}=328.9 \pm 0.8 \mathrm{~K}, \Delta H=73.6 \pm 2.7 \mathrm{kcal} \mathrm{mol}^{-1}\right)$, suggesting that the folding stability of unphosphorylated GarA originates largely in the well-structured FHA domain, with the N-terminal extension playing a marginal role in maintaining the overall structure of the protein.

\subsection{Phosphorylation promotes self-recognition}

Biochemically characterized FHA modules are known to bind pThr-containing peptides and proteins $[14,15]$. This is also the case for GarA, since we have previously demonstrated that the association of GarA with both PknB and PknG strongly depends on the phosphorylation state of these protein kinases, with their pThr residues acting as secondary docking sites for substrate recruitment $[7,9]$. Moreover, important residues for pThr-binding in FHA domains (such as Arg81, Ser95 and Arg96) are also highly conserved in GarA homologs from actinomycetes [7]. These observations strongly suggest that structuring of the N-terminal extension upon phosphorylation may involve the self-recognition of the phosphorylated N-terminal segment by the C-terminal FHA domain of GarA.

To validate this self-recognition model, we measured the interaction of $\operatorname{GarA}_{\Delta 43}$ with two synthetic 17-residue peptides (either phosphorylated or unphosphorylated at Thr22) corresponding to the N-terminal region of GarA and centered on the phosphorylatable threonine. As expected, only the phosphorylated peptide is able to bind $\operatorname{GarA}_{\Delta 43}$ with a 1:1 stoichiometry (experimental value $0.985 \pm 0.025$ ) and a submicromolar affinity, whereas no interaction could be detected under the same experimental conditions for the unphosphorylated peptide (Fig. 4A). These experiments clearly demonstrate that the FHA domain of GarA binds its own N-terminal peptide extension, but only when the latter is phosphorylated, suggesting that unphosphorylated GarA (i.e. with a vacant pThr-binding site) could interact with other phosphorylated proteins, besides protein kinases, as part of its cellular function(s).

\subsection{Biological implications}

The physico-chemical and structural studies described above lend strong support to a model of GarA acting as a molecular switch in phosphorylation-dependent regulation mechanisms. Importantly, GarA is a substrate not only of different protein kinases, but also of the $M$. tuberculosis protein phosphatase PstP in vitro (data not shown). Although in our hands the GarA dephosphorylation reaction is not as efficient as in the case of PstP-mediated dephosphorylation of $\mathrm{PknB}$ [16], genetic studies have recently shown that dephosphorylation of OdhI, the GarA homolog in C. glutamicum, is indeed catalyzed by ppp, the corynebacterial
PstP homolog [17], thus indicating that GarA/OdhI can undergo reversible phosphorylation in vivo.

According to our model, the unphosphorylated form of the protein displays a structurally flexible $\mathrm{N}$-terminal peptide and a free pThr-binding site, both of which are accessible for interaction with (and modulation of) other proteins (Fig. 4B). The phosphorylation of the N-terminal extension of GarA by PknB at Thr22 (or PknG at Thr21) would then promote the tight intra-molecular interaction between the $\mathrm{N}$-terminal pThr-containing region and the FHA domain, thus effectively switching off the regulatory function(s) of the protein. The phosphorylated N-terminal extension of GarA should outcompete other phosphorylated proteins for binding to the FHA domain due to the combined effect of: (1) a relatively high (submicromolar) binding affinity of the FHA domain for the separate $\mathrm{N}$-terminal phosphopeptide (as shown in Fig. 4A), and (2) a higher effective local concentration because these two interaction partners are covalently linked in a single polypeptide.

Previous work demonstrated that $M$. smegmatis GarA is involved in the regulation of glycogen accumulation during the exponential phase of bacterial growth [10]. More recently, it was reported that C. glutamicum OdhI binds to and inhibits OdhA, the E1o subunit of 2-oxoglutarate dehydrogenase in the TCA cycle [8]. The inhibition is relieved when OdhI is phosphorylated by PknG, indicating that OdhI regulates glutamate production in corynebacteria [17]. We obtained similar results in mycobacteria, where the unphosphorylated form of GarA was found to bind and modulate not only the enzymatic activity of the OdhA homolog, $\alpha$-ketoglutarate decarboxylase, but also that of a large $\mathrm{NAD}^{+}$-specific glutamate dehydrogenase [9]. Our proposed self-recognition model can explain these observations, because GarA was found to interact with its downstream partners only in its unphosphorylated form [9]. More generally, recent studies of bacterial phosphoproteomes tend to confirm the presence of a significant number of proteins that are phosphorylated at Ser/Thr at some point in their functional cycle [18-20]. Since many of these phosphoproteins could be the target of the GarA FHA domain, it could therefore be expected that forthcoming functional studies will unveil additional regulatory functions of GarA/OdhI acting as a phosphorylation-dependent molecular switch in actinomycetes.

\section{Acknowledgements}

This work was supported by grants from the Institut Pasteur, the CNRS (France) and the European Union (NM4TB, Contract No. LSHP-CT-2005-018923). The authors gratefully acknowledge the professional technical assistance of J. d'Alayer, F. Groh, I. Miras and V. Bondet. Finally we thank Dr. M. Bellinzoni for helpful advice and constructive criticism.

\section{References}

[1] Pawson, T. (2007) Dynamic control of signaling by modular adaptor proteins Curr. Opin. Cell Biol. 19, 112-116.

[2] Cole, S.T. et al. (1998) Deciphering the biology of Mycobacterium tuberculosis from the complete genome sequence. Nature 393, 537-544.

[3] Wehenkel, A., Bellinzoni, M., Graña, M., Durán, R., Villarino, A., Fernandez, P., Andre-Leroux, G., England, P., Takiff, H., Cerveñansky, C., Cole, S.T. and Alzari, P.M. (2008) Mycobacterial Ser/Thr protein kinases and phosphatases: physiological roles and therapeutic potential. Biochim. Biophys. Acta 1784, 193-202.

[4] Durocher, D., Henckel, J., Fersht, A.R. and Jackson, S.P. (1999) The FHA domain is a modular phosphopeptide recognition motif. Mol. Cell 4, 387-394.

[5] Pallen, M., Chaudhuri, R. and Khan, A. (2002) Bacterial FHA domains: neglected players in the phospho-threonine signalling game? Trends Microbiol. 10, 556563.

[6] Hammet, A., Pike, B.L., McNees, C.J., Conlan, L.A., Tenis, N. and Heierhorst, J. (2003) FHA domains as phospho-threonine binding modules in cell signaling. IUBMB Life 55, 23-27.

[7] Villarino, A., Duran, R., Wehenkel, A., Fernandez, P., England, P., Brodin, P., Cole, S.T., Zimny-Arndt, U., Jungblut, P.R., Cerveñansky, C. and Alzari, P.M. (2005) 
Proteomic identification of Mycobacterium tuberculosis protein kinase substrates: PknB recruits GarA, a FHA domain-containing protein, through activation loop-mediated interactions. J. Mol. Biol. 350, 953-963.

[8] Niebisch, A., Kabus, A., Schultz, C., Weil, B. and Bott, M. (2006) Corynebacterial protein kinase $G$ controls 2-oxoglutarate dehydrogenase activity via the phosphorylation status of the OdhI protein. J. Biol. Chem. 281, 12300-12307.

[9] O'Hare, H.M., Durán, R., Cerveñansky, C., Bellinzoni, M., Wehenkel, A., Pritsch, O., Obal, G., Baumgartner, J., Vialaret, J., Johnsson, K. and Alzari, P.M. (2008) Regulation of glutamate metabolism by protein kinases in mycobacteria. Mol. Microbiol. 70, 1408-1423.

[10] Belanger, A.E. and Hatfull, G.F. (1999) Exponential-phase glycogen recycling is essential for growth of Mycobacterium smegmatis. J. Bacteriol. 181, 6670-6678.

[11] Allen, D.L. and Pielak, G.J. (1998) Baseline length and automated fitting of denaturation data. Protein Sci. 7, 1262-1263.

[12] Alderwick, L.J., Molle, V., Kremer, L., Cozzone, A.J., Dafforn, T.R., Besra, G.S. and Futterer, K. (2006) Molecular structure of EmbR, a response element of Ser/Thr kinase signaling in Mycobacterium tuberculosis. Proc. Natl. Acad. Sci. USA 103, 2558-2563.

[13] Myers, J.K., Pace, C.N. and Scholtz, J.M. (1995) Denaturant m values and heat capacity changes: relation to changes in accessible surface areas of protein unfolding. Protein Sci. 4, 2138-2148.

[14] Durocher, D., Taylor, I.A., Sarbassova, D., Haire, L.F., Westcott, S.L., Jackson, S.P., Smerdon, S.J. and Yaffe, M.B. (2000) The molecular basis of FHA domain: phosphopeptide binding specificity and implications for phospho-dependent signaling mechanisms. Mol. Cell 6, 1169-1182.

[15] Li, J., Williams, B.L., Haire, L.F., Goldberg, M., Wilker, E., Durocher, D., Yaffe, M.B., Jackson, S.P. and Smerdon, S.J. (2002) Structural and functional versatility of the FHA domain in DNA-damage signaling by the tumor suppressor kinase Chk2. Mol. Cell 9, 1045-1054.

[16] Boitel, B., Ortiz-Lombardia, M., Duran, R., Pompeo, F., Cole, S.T., Cerveñansky, C. and Alzari, P.M. (2003) PknB kinase activity is regulated by phosphorylation in two Thr residues and dephosphorylation by PstP, the cognate phospho-Ser/Thr phosphatase, in Mycobacterium tuberculosis. Mol. Microbiol. 49, 1493-1508.

[17] Schulz, C., Niebisch, A., Gebel, L. and Bott, M. (2007) Glutamate production by Corynebacterium glutamicum: dependence on the oxoglutarate dehydrogenase inhibitor protein OdhI and protein kinase PknG. Appl. Microbiol. Biotechnol. 76, 691-700.

[18] Bendt, A.K., Burkovski, A., Schaffer, S., Bott, M., Farwick, M. and Hermann, T. (2003) Towards a phosphoproteome map of Corynebacterium glutamicum. Proteomics 3, 1637-1646.

[19] Macek, B., Mijakovic, I., Olsen, J.V., Gnad, F., Kumar, C., Jensen, P.R. and Mann, M. (2007) The serine/threonine/tyrosine phosphoproteome of the model bacterium Bacillus subtilis. Mol. Cell Proteom. 6, 697-707.

[20] Macek, B., Gnad, F., Soufi, B., Kumar, C., Olsen, J.V., Mijakovic, I. and Mann, M. (2008) Phosphoproteome analysis of $E$. Coli reveals evolutionary conservation of bacterial Ser/Thr/Tyr phosphorylation. Mol. Cell Proteom. 7, 299-307. 